Aiste Barbora Uspuriene doctor of pedagogic sciences, lecturer Žygimantas Janavičius master's degree student Lithuanian Sports University Kaunas, Lithuania

\title{
PECULIARITIES OF ELITE BASKETBALL PLAYERS TRAINING
}

Abstract: research on elite basketball players is important to remain among the leaders, to predict their sports future, to adjust the course of training, a proper database is needed. Research aim - to analyze the literature and to reveal elite basketball players training peculiarities.

Keywords: basketball, physical fitness, nutrition, intensity.

Ушпурене Айсте Барбора д-р пед. наук, преподаватель, лектор

Янавичюс Жигимантас магистрант Литовский университет спорта

г. Каунас, Литовская Республика

DOI $10.21661 / \mathrm{r}-553224$

\section{ОСОБЕННОСТИ ПОДГОТОВКИ ВЫСОКОКВАЛИФИЦИРОВАННЫХ БАСКЕТБОЛИСТОВ}

Аннотация: исследование подготовки высококвалифицированных баскетболистов необходимо для того, чтобы оставаться в лидерах; для того, чтобы предугадать их спортивное будущее, отладить программу тренировок, необходима соответствующая база данных. Целью исследования является анализ литературы для выявления особенностей подготовки высококвалифицированных баскетболистов. 
Ключевые слова: баскетбол, физическая подготовка, питание, интенсивHOCMb.

\section{Introduction}

Elite basketball players differ from low-trained in the level of physical development and the capacity of body functions. The central nervous system, muscles, cardiovascular systems of such basketball players are adapted to the high loads required for the sport and the maintenance of high working capacity for a long time (Safaric and Bird, 2011). Research on the training of highly skilled basketball players is important to remain among the leaders, predict their sporting future, adjust the course of training, a proper database is needed.

Research aim - to analyze the literature and to reveal elite basketball players training peculiarities.

\section{Results and Conclusions}

The literature analyzing the training of elite basketball players indicates that their anthropometric indicators, nutrition, muscle power, endurance of repetitive work, psychomotor response and other aspects are important for elite basketball players.

It is argued that the actions of a basketball player may be determined by their physical development, i. e. their height, limb length, body weight, muscle and fat mass (Masanovic et al., 2019). Looking at the height of the players, it is not possible to unambiguously assess this indicator - higher players find it easier to reach the basket, easier to reach a high-flying ball, as well as create opportunities to throw into the basket; meanwhile, lower players can run faster, drive the ball more easily, change body position, and so on (Masanovic et al., 2019).

To maintain a high level of performance, the amount of energy that is obtained during the diet must be adequate for energy intake, and the nutrients that provide energy must be balanced with each other. G. Ziv and R. Lidor (2009) stated, that energy consumption should be balanced between carbohydrates (55-58\% energy), protein (12-15\%) and fat (25-30\%). Particular attention should be paid to vegetarian athletes who may be at risk of low protein intake as well as low micronutrient intake (especially vitamin B12, zinc, iron and calcium). While most macronutrients and micronutrients 
can be sourced from a balanced diet, additional supplements can be beneficial during the intense basketball season (Ziv and Lidor, 2009).

The physical capacity of elite basketball players is specific, as the power of short muscle work is especially significant during competitions (Tsoufi et al., 2016). Muscle work power is defined as the compatibility of speed and force during work. Muscle power is required to perform a variety of actions: to recapture the ball, to make an effective pass, trying to effectively push to the basket, and so on (Santos and Janeira, 2008).

Psychomotor reaction and speed of movements are realized during various competition situations: quick start of movement, quick change of body position, fast throwing of the ball (Mańkowska et al., 2015). Therefore, the speed of the basketball player's hand movements and its manifestation (dexterity) is important.

\section{References}

1. Mańkowska M, Poliszczuk T, Poliszczuk D, Johne M. Visual perception and its effect on reaction time and time-movement anticipation in elite female basketball players // Polish Journal of Sport and Tourism - 2015 - Vol. 1. - P. 3-8.

2. Masanovic B, Popovic S, Bjelica D. Comparative study of anthropometric measurement and body composition between basketball players from different competitive levels: elite and sub-elite // Pedagogy of Physical Culture and Sports - 2019 Vol. 4.

3. Safaric AJ, Bird SP. Agility drills for basketball: Review and practical applications // Journal of Australian Strength Conditioning - 2011 - Vol. 4. - P. 27-35.

4. Santos EJ, Janeira MA. Effects of complex training on explosive strength in adolescent male basketball players // The Journal of Strength \& Conditioning Research - 2008 - Vol. 3. - P. 903-909.

5. Tsoufi A, Maraki MI, Dimitrakopoulos L, Famisis K, Grammatikopoulou MG. The effect of professional dietary counseling: elite basketball players eat healthier during competition days // The Journal of sports medicine and physical fitness - 2016 Vol. 10. - P. 1305-1310. 
6. Ziv G, Lidor, R. Physical attributes, physiological characteristics, on-court performances and nutritional strategies of female and male basketball players // Sports Medicine - 2009 - Vol. 7. - P. 547-568. 